\title{
THE CHANGE IN THE UNDERSTANDING OF ZWINGLI IN RECENT RESEARCH*
}

\section{Gottrried W. Locher, Professor in Historical and Systcmatic Theology, Bern, Switscrland}

\section{The Problem}

The editors of Vox Theologica have asked me for a "survey of Zwingli research in the last five to ten years." However, to understand this subject thematically and methodologically one must go farther back. For the prevailing image of Zwingli today has been formed by three well-known books: 1) Dic Kirchenratsauswahl, 1918; 2) Paul Wernle, Zwingli, 1919; 3) Walther Köhler, Huldrych Zwingli, 1943/1954. Walther Köhler (1870-1946), a native of strongly Reformed Wuppertal-Elberfeld, Professor of Church History in Zürich from 1909 to 1929, himself theologically of liberal orientation, was one of the foremost authorities not only on the Reformation as a whole but also on the other movements of the sixteenth century, especially Humanism and Anabaptism. Through countless books, articles and reviews, and through his introductions in the great critical edition of Zwingli's works, he became actually the dean of Zwingli research. Even those who, like this writer, did not know him personally and who differ from him on essential points owe him reverence. ${ }^{2}$ Characteristic of the image of Zwingli as seen, formulated and disseminated by Köhler is the well-authenticated ${ }^{3}$ anecdote according to which he once praised, in the presence of his students, the well-known monument behind the Wasserkirche in Zürich which impressively represents the Reformer armed with Bible and sword, but added that one must really imagine the Book as having each page of the Greek New Testament followed by a page from Plato's Dialogues. Implied is that Zwingli was and remained essentially a Humanist: "He got the Reformation from Luther"; the antithesis between the humanisticclassical elements and the biblical-Christian elements extends through his whole nature and indeed through his character. ${ }^{4}$ In the aforementioned brief work of $1943\left(1954^{2}\right)$, in which he summarized his life-work as a researcher, Köhler defended his thesis in a most moderate fashion and toned down both sides of the "antithesis." Zwingli's independence vis-à-vis Luther is presented much more strongly, the genuineness of his conformance to Pauline anthropology is documented, and the change in his Humanism vis-à-vis that of Erasmus is worked out. But basically the picture of the two different lines in Zwingli's thought remains, the one representing the biblical and Reformation elements and the other the humanistic elements. The lines converge only because of the Reformer's "strong will towards unity" but ma-

*'Die Wandlung des Zwingli-Bildes in der neueren Forschung," Zwingliana XI/9 (1963), 560-585. Translated by Kenneth Hagen. 
terially remain unconnected. ${ }^{5}$ It is to be emphasized that for Walther Köhler the discovery of this dichotomy by no means implies a reproach. Rather, a connection with the tradition of classical antiquity gives Christianity, especially the Reformation, the possibility and ability to influence culture and to refine it in the sense of a general spiritual renewal. Zwingli is to be highly esteemed in that he-in contrast to Luther-was consciously aware of the necessity of this. One cannot entirely avoid the impression that the great historian, dedicated to complete objectivity, was inspired by the secret desire to find in the circle of the Reformers a special father of liberal theology.

But on closer examination one sees that at the basis of this concern and attempt to present a divided $Z$ wingli lies an assumption of four hundred years standing, taken over uncritically from the German reading of the history of dogma: Martin Luther is the Reformer. Luther's inner development, his way and, finally, his conception of doctrine provide the standard for evaluating all Reformation efforts. Luther is made the normative Reformer. Whatever conforms to his picture is regarded as valid, but that which does not, is regarded as alien. Here we can leave it an open question whether one thereby really honors Luther or even understands him; certainly one runs into difficulty already with Calvin and even more so with Melanchthon. However, the application of this method, which one finds in all the textbooks, to the study of Zwingli implies: Chapter 1: Luther became a Reformer thus and so, and as such, he said this and that. Chapter 2: Zwingli, a Humanist, also became a Reformer without going through Luther's cloister experience and spiritual struggles. On most points he agrees with Luther, but there are the following differences, etc. Thus the points of difference (for example, the doctrine of the Lord's Supper or of the state) are torn out of their context in Zwingli's thought and overemphasized; and, what is just as dangerous, the points of agreement (the doctrine of grace, repentance, servum arbitrium), their characteristic place and function in Zwingli's thought, are overlooked. In short, $Z$ wingli must be studied in the light of his own motives and understood from his own presuppositions. Possibly then an unexpected spiritual form with its own integrity will emerge which may well correspond to his supremely calm and serene style. This is, it seems to me, the main task of $Z$ wingli research today.

\section{Report on Research}

1. For our generation to understand the Reformers it is necessary to have a critical edition of their Opera with introductions and explanations which meets the demands of philological and historical science. In this respect $Z$ wingli has been fortunate. The complete edition prepared by Professors Melchior Schuler and Johannes Schulthess in connection with the 1819 celebration of the Reformation in 
Zürich has become a model for similar efforts. ${ }^{6}$ The text and for the most part also the dating are reliable. For years to come a number of important writings will be available only in this edition. ${ }^{7}$ So also, as the new edition progresses, this old edition will of course become less expensive on the secondhand market; those interested should seize the opportunity.

To be sure, modern demands are clearly met in the Sämtlichen Werke initiated by Emil Egli. ${ }^{8}$ Its appearance was delayed by two World Wars and the Iron Curtain, and research was thereby severely curtailed. Nevertheless, in spite of isolated errors or deficiencies in the apparatus, no catastrophies have occurred, as they did in the Weimar edition of Luther's works, where whole volumes can be used only with caution, and the edition of Calvin's works in the Corpus Reformatorum, which was prematurely terminated. The Zwingli society in Zürich, under its energetic president, Leonhard von Muralt, Professor of modern and Swiss history in Zürich, has for some years now given renewed impetus to publishing. As a result. Zwingli's treatises and documents, etc. up to the year 1528 (Vols. I-VI) are now ready, as well as the entire correspondence (Vols. VII-XI), the four parts to Vol. XII (Marginal Glosses), and the complete Vols. XIII and XIV (Exegetica). Still missing are the writings of the last years (1529-1531), and the remainder of the Exeaetica. Egli's prospectus and the appearance of hitherto unknown writings ${ }^{9}$ will certainly give rise to several special volumes of sermons-until lately we possessed only a few revisions and expansions of Zwingli's sermons. In the notes of the Werke there is a wealth of labor and instructive scholarship. The student is particularly advised to note the short and longer excursus on the history of dogma by Fritz Blanke.

Now for a look at some editions of selected works. The aforementioned Kirchenratsausgabe is still widely circulated. ${ }^{10}$ One should be immediately warned here for two reasons. First of all, the book gives a one-sided picture, because the writings were abbreviated in such a manner that the quotations and examples from antinuity which Zwingli used to confirm his arguments were retained in their entirety while the even more copious and comnrehensive "testimonia" from Holy Scripture were omitted. Secondly, the translation teems with errors which distort the meaning. The editors, otherwise acknowledged as highly conscientious, were not able to check carefully enough on their co-workers because of the pressure of time. Fortunately this book has recently been replaced by a good revision. ${ }^{11}$ Edwin Künzli has, to be sure, gone back to the old Kirchenratsausgabe, but he has extensively modified it, newly translated whole sections and, what is particularly praiseworthy, added a sixth part: "The Reformer's Use of the Bible," with examples from Zwingli's translation and exegesis. 
At last, now, we have a synoptic view of the real Zwingli in one compact volume!

The convenient Zuingli-Hauptschriften, ${ }^{12}$ ambitiously begun in 1940, have apparently come to a halt because they offer too little for the professional researcher and presume too much from the layman. Furthermore, it is difficult for the present-day Swiss to become accustomed to Zwingli's South German. Hopefully, at least the second half of Blanke's excellent translation of the Commentarius de vera et falsa religione will still appear. This "Commentary" of 1525 was the first evangelical systematic theology and influenced Calvin's Institutio on several not insignificant points. Desperately needed is a selection of Zwingli's writings in the original Latin or German text together with an accompanying translation into contemporary German. There is reason to be grateful for the appearance of "A token of friendship from a Union Lutheran": Gerhard G. Muras, minister of the evangelical Lutheran congregation in Bern and experienced editor of Texten aus der Theologie-geschichte des Protestantismus, has undertaken a translation of the Anleitung of 1523 into modern German for the Furche-Bücherei. ${ }^{13}$ The fine translation of the Reformer's Briefen by Oskar Farner also remains incomplete. ${ }^{14}$ Zwingli's political views, with their theocratic and hence republican and critical attitude vis-à-vis the state, once again have been of assistance in strengthening our national consciousness and our readiness to resist in the years of the threat from the Third Reich. ${ }^{15}$ In French there is only a small selection of Zwingli's works available. ${ }^{16}$ The English edition progresses slowly. ${ }^{17}$ Not to be forgotten is the brilliant Dutch rendering of the 67 Artikel and the Christlichen Einleitung by G. Oorthuys. His work came to fruition in a series of highly esteemed articles in Troffel en Zwaard. ${ }^{18}$

2. Oskar Farner was for decades preacher in Zwingli's pulpit in the Grossmünster in Zürich and president of the cantonal consistory. In addition, he was a Privatdozent and later Honorarprofessor at the University. As such he acquainted innumerable students with Zwingli and won many for Zwingli research. It was almost granted him to complete his broadly conceived Biographie of Zwingli. Rudolf Pfister, ${ }^{19}$ successor to Farner's professorship, conscientiously and ably completed and published the fourth volume. Superseding all its predecessors, this Biographie for the foreseeable future is the standard work on the development and influence of the Zürich Reformer. Farner's books are characterized by continual reference to the sources, not a few of which he discovered himself, by exact knowledge of research in the field and precise summary of its results, by good organization of the material and sound reasoning, together with a brilliant talent for narrative and a forceful language obviously trained 
in Zwingli research. They vividly portray the cultural and historical milieu of Zwingli's peasant origins, his scholastic education, humanistic development, decision for reformation, and his municipal as well as confederate activities. One is almost able to participate in the Reformer's relations with opponents and friends, magistrates and populace. One can actually see here how church history develops, namely, in a very earthy and mundane way. But this strength of the book has its reverse side: Zwingli's history remains at time confined to local history, so that neither its broader influence nor the problematic receive their due. This was by no means necessary, since after all Farner himself, originally a liberal, was led through his work on Zwingli to a Pauline faith in Christ, and to a decisive and public stand for the Confessing Church in Germany and its Barmen Declaration. Farner's concentration on Zürich gives the reader occasion to consult the aforementioned late work of Walther Köhler ${ }^{20}$ and compare it with these four volumes. One can characterize the difference between the two works in this way: Farner knows in which Gasthaus Zwingli occasionally ate supper, and in which house his opponents gathered at the same time, as well as the reasons why they resented him, reasons which were in part very personal. Köhler is acquainted with the business relationships between Zürich, Venice and Lyon, and is familiar with Zwingli's friends in Paris. He also knows what advice they gave him to advance his plans for federation, and what propositions in the confessional documents sent to him would have been agreeable to a person like Francis I. Farner is more a church historian, whereas Köhler is also an historian of Christian thought. And whereas in Köhler's work the image of the Humanist predominates, Farner is in danger of allowing Zwingli's Humanism to disappear under the image of the people's politician. ${ }^{21}$

One more detail: For a long time an old painting of a man's head was displayed in the Czernin Gallery in Vienna. Oral tradition maintained, a) that Albrecht Dürer painted it and b) that it depicts Zwingli. Both opinions drew only laughter. A cleaning of the picture in 1945 revealed Dürer's signature and its origin was established beyond all doubt. Then the question was posed whether or not the other part of the tradition might also be correct. The Zürich art historian, Professor Hans Hoffmann, takes an affirmative position in Vol. II of Farner's biography where a photographic reproduction is furnished. The painting was offered to Zürich for a million Swiss franks during an exhibition in the city, but no decision could be made in spite of the readiness of the patrons, because the historians and art historians could not agree on a recommendation. ${ }^{22}$ Today the picture which was sold for a million dollars hangs in an American Museum. ${ }^{23}$ It portrays a roundheaded young man with sharp features, energetic chin, slight sensually curved lips, raised broad-tipped nose, reddish hair 
and fiery eyes. The left eye is opened somewhat wide as is the case with the near-sighted. Date: A.D. $1516 .^{24}$ This would be a painting of the pre-Reformation Zwingli, the secular priest in Glarus, who even then had participated in a campaign in southern Italy. It would be the only painting made during his lifetime, and too a painting of highest artistic quality. The other known pictures are posthumous. I hope in the near future to publish proof of its authenticity and suggest as a possible date and place of origin the winter of 1516, Basel, where both Dürer and Zwingli sojourned and visited the house of Erasmus of Rotterdam.

3. But more important than Zwingli's physiognomy is one's interpretation of the intellectual image of the man and his inner development. Oskar Farner, who, as a student of Wernle in his early years, was of the same mind as Köhler, strongly emphasizes in the second volume of his biography, the independence of the Swiss Reformer and his slowly maturing realization that his growing evangelical convictions must risk revolt against the Papal Church. ${ }^{25}$ His breakthrough to an irreversible decision took place after his experience of the plague in 1520. This is determined on the basis of a famous letter to Myconius and the beautiful hymn on the plague full of thankfullness for recovery from illness.

Around the same time as Farner, Arthur Rich tackled the old problem of Zwingli's development with a careful and illuminating investigation, and virtually found its solution. ${ }^{26}$ Rich demonstrates that Zwingli's understanding and program of the christianismus renascens was until 1520 determined by Erasmus and, therefore, by his humanistic training ${ }^{27}$-on January 1,1519 , he took up his position in Zürich. Even the well-known fact that Zwingli read Luther and circulated many of his writings, which has always been an argument against Zwingli's later assertion of his independence from Luther, was due to a misunderstanding on Zwingli's part which saw Luther as a spiritual ally and companion in the battle for the Erasmian renaissance of Christianity through a philosophia christiana. But "at that moment, when Zwingli begins to lose confidence in the method of restoring Christianity with the humanistic program, his interest in ... the Lutheran writings ceases."28 The Swiss Reformer was not the student of the Wittenberg Doctor. To be sure, Zwingli was greatly influenced by Luther's example, remarkably enough, however, not that of Worms, but that of Leipzig-perhaps precisely because according to the rules of the late mediaeval university the Leipzig Disputation resulted in a defeat for Luther. In his confession, ready for sacrifice and unconcerned about the consequences, Luther became for Zwingli an "Elijah," a "Hercules."29

We have had in our possession now for a few months an ex- 
ceedingly learned monograph. Its fifty-six pages of scrupulous exactitude demand patience and diligence from the reader, though they will reward him with clear insights into important relationships. Joachim Rogge set on his desk the early writings and letters of Zwingli alongside the same sort of books by Erasmus and carefully compared their statements, train of thought and argumentation, yes, even their wording $;^{30}$ Luther is also cited. The structure of the pamphlet's eighteen short chapters is clear and well-devised and its argument convincing. It is recognized that "war and peace" is not only an idealistic motif in a passing phase of Zwingli's development, but also a permanent "general theme" in his thought. Unlike the knowledgeable author, I am of the opinion that the army chaplain from Glarus described the Pavia campaign on grounds of his own experience. ${ }^{31}$ I conclude this not only, as many did before, on the basis of the liveliness of the account with its innumerable particulars, but especially on the basis of the usage and meaning of a number of terms and their changes in late Latin. However, this is not important. The results of this North German scholar seem to me, taking everything into account, to point in the same direction as our recent Swiss research: the remarks of the young Zwingli show that he was a student of Erasmus, not of Luther. "To be sure neither Reformer was ever unconditionally Erasmian" (p. 47). I would think, however, that as far as an ardent confederate could ever follow a cosmopolitan, Zwingli did it for a while "unconditionally." But then he was "repelled by .Erasmus because he discovered in the great teacher a lack of immediate results" (Ibid.). Zwingli departed from Erasmus rot only because of political and ecclesiastical reasons, but also because Zwingli's "results," his Reformation stand, arose from his newly discovered, radical understanding of the biblical message of God's judgment and God's grace. This understanding went deeper than the philosophia christiana of Humanism.

In my opinion a remark must still be added about the old controversy over the question whether the beginnings of Zwingli's Reformation insight are to be dated in 1520/21 in Zürich, according to the school of Köhler, Farner, Rich, Blanke and others, or according to Zwingli himself, Bullinger and the old school, already in 1516 in Einsiedeln. Basically this is not an historical question, but a theological one. It depends upon whether one regards the essence of the Reformation to be Zwingli's conscious doctrinal acceptance of Pauline anthropology, which one can actually find in Zwingli only after the plague experience, or-and this was Zwingli's own claim-to be already the scriptural principle and his experience of the Christus praesens bound to it. ${ }^{22}$

4. Thus we arrive at the question of Zwingli's anthropology which 
was seized upon already by Luther with great mistrust. Ever since, throughout the centuries and in nearly all the textbooks, the claim re-

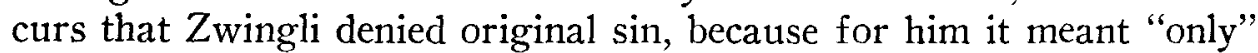
a "presten," a transgression. There is no doubt, that precisely in his anthropology, Zwingli's Humanism remained especially influential. He maintained throughout his life a Platonic-Stoic dualism, which he combined with his Christian spiritualism in his own particular way. Oorthuys demonstrated in a dissertation ${ }^{33}$ as early as 1905 that the usual interpretation misunderstands Zwingli's doctrine of original sin and his rejection of "original guilt." Strangely enough it was this Dutchman who was the first to notice that Luther as a Middle German had linguistically misunderstood the Southern German "presten." It means "breach," incurable "rupture." Rudolf Pfister ${ }^{34}$ showed that it was actually not due to Pelagian but to Pauline tendencies that led Zwingli to abandon the traditional doctrine of original sin. Personal guilt presupposes a divine law, not a biological fate. The result of the discussion ${ }^{35}$ at present is as follows: Morbus, "presten," characterizes sin as "sickness unto death," according to Zwingli, that is, as the compulsion in which every man is subject a) to $\sin$ and b) to death; and noetically it refers c) to our complete blindness to revelation. However, man becomes "guilty" only in the commission of sin. This-purely theoretical-distinction between original sin and original guilt is intended to avoid giving the sinner the possibility of imagining that his action is fated and inevitable and thus, in the final analysis, passing himself off as not guilty. Understood in this manner, Zwingli's formulations do not weaken but reinforce the Reformation concept of $\sin$.

5. The long and well-known fact that Zwingli of all Reformers was the most extreme exponent of the doctrine of election should have alerted one against such a misunderstanding. Perhaps in his formulation of peccatum originale he wished to remove the impression of determinism to which he had nearly capitulated in his intimate connection of providentia and praedestinatio, adopted from Thomas Aquinas. The charge of determinism, among other things, may have been leveled against $Z$ wingli when Calvin so decisively distinguished between providence and predestination in the 1559 Institutio. ${ }^{36}$ But is not the traditional understanding of Zwingli really correct in finding a moralism rooted precisely in his doctrine of election, according to which man is in a position to reach final blessedness with his own good powers without the aid of the biblical message? How else, as the famous passage in Fidei expositio claims, could Hercules, Theseus, Socrates and the Catos reach heaven along with Abraham, Moses and David ${ }^{37}$ Is it not understandable that Luther became very angry with Zwingli when this writing appeared in 1536, that Wernle acknowledges this to be a "moralistic universalism," 38 and Köhler speaks of "a hu- 
manistic appraisal of man" and "a break in the exclusivistic Christian understanding of salvation"39? Is not synergism here apparent and even more so the relativizing of revelation?

Rudolf Pfister devoted a lively and fundamental investigation to the question. ${ }^{40} \mathrm{He}$ shows step by step in what sense Zwingli's statements about the "pious heathen" are to be understood. It is not a question of an anthropological but a theological assertion, that is, not of a possibility present in every man, but of the definite election of definite men also outside the biblical sphere. Secondly, it is not a question of a shift from faith to human subjectivity, but of a shift in accent from faith to election, from the subjective to the objective presupposition of redemption. This is also noticeable in other aspects of $Z$ wingli's development. There is for Zwingli no genuine faith without election, but the reverse may be true, as demonstrated by the children born in the covenant, the heathen before being missionized, indeed all of us before our conversion. Thirdly, Christ is not overlooked in this but, on the contrary, his honor is increased. For it remains definite: "Per Christum accedere oportet, quicumque ad deum veniunt." ${ }^{41}$ Through election" and "through Christ" are the same: "Electio igitur est quae salvum facit, sed per Christum; hoc est: Deus .. . quos vult beatos, sed per Christum; hoc est: per se ipsum, per bonitatem et gratiam." ${ }^{\prime 2}$ The sacrifice of Christ is imputed to the elect, even the elect among the heathen. In this manner they are reconciled with the Father in Christ and attain salvation.

I can augment Pfister's argumentation with a further reference. ${ }^{43}$ When Zwingli speaks of the Atonement, he repeatedly cites I John 2:2: "Christ is the propitiation for our sins, and not for ours only, but also for those of the whole world." In principle election and universalism exclude one another, but $Z$ wingli intends to say that the freedom of God expressed in election, postulates universalism and forbids the drawing of boundaries by our standards. The sacrifice of Christ, finally, is basically universal. Otherwise redemption would be less than the corruption caused by sin and Christ would be inferior to Adam. ${ }^{44}$

Thus the problem of the relation between satisfactio and praedestinatio is posed. No Reformer perceived the problem so clearly and solved it so boldly as $Z$ wingli. It would have been well if this voice had not remained unheard in the Reformed Church in its development of the doctrine of election. It would perhaps have allowed the light which this doctrine possesses to shine more clearly-this light would not have turned itself so often into gloomy shadows. Calvinism draws two lines ${ }^{45}$ : God's goodness elects us and redeems us in Jesus Christ; God's righteousness leaves the rest of mankind in their damnation. Zwingli allows only one valid line: God's goodness elects through 
Christ and his righteousness appropriates the salvation acquired by Christ to the elect. God is "righteous" in himself and in relation to us, in that he deals with us according to what Christ has done for us. "Bonitatis est elegisse quos velit; iustitiae vero electos sibi adoptare et iungere per filium suum, hostiam ad satis dandum divinae iustitiae pro nobis factum." ${ }^{46}$ Rejection is hardly mentioned; it may be interpreted according to the thought of the young Augustine, in the sense of practeritio. ${ }^{47}$

6. The specialist is already well aware that the center of $Z$ wingli's doctrine of predestination is the freedom of the Holy Spirit. Indeed one of the main elements of Zwingli's theology in general is his spiritualism. Now we come to that critical part of his spiritualism which so often has brought fame and infamy, recognition and antipathy, to the name of the Reformer from Zürich, and caused so much misunderstanding among disciples and opponents. Essential to his doctrine of the Lord's Supper is his faith in the glorified Christ and the Holy Spirit. We are well aware that friends as well as opponents have often simply identified this spiritualism with rationalism and still continue to do so. But here one must be particularly careful.

One of the accomplishments of the old school of self-denying German scholarship is Köhler's reconstruction of the Marburg Colloquy. ${ }^{48}$ It inspires the highest degree of respect. From twenty-seven greater and lesser sources (reports and letters), he reconstructed a "protocol" of the discussion. It convincingly recounts the progress and content of the debate. The present-day researcher who does not only dwell on the exegetical and scholastic-philosophical details, but wishes to penetrate to the heart of the argument is astounded how clearly this was also the objective of the participants. "Oecolampadius: 'Don't depend so much on the humanity and the flesh of Christ, but lift your mind to the divinity of Christ!' Luther: 'I know no other God than the one who became man, nor will I have any other.' "49 Luther's irritability breaks through repeatedly: "I don't care what you teach in Strasbourg. So if you won't have me or my doctrine, then I also cannot bear to have you as disciples." "50 The whole complicated relationship (certainly never unambiguous!) between "Humanism," "the Reformation" and "the Bible" is exposed. As the discussion turns to Christology Zwingli cites Phil. 2:6ff: "Zwingli: 'It says, "O 5 है v

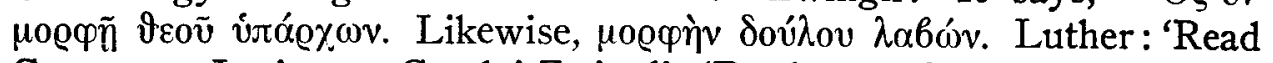
German or Latin, not Greek.' Zwingli: 'Pardon me for using the Greek

Testament. I have been using it for twelve years, I have only once read the Latin.'

This reconstruction, occasionally stenographic, was a by-product of Walther Köhler's great Opus on the controversy over the Lord's Supper, "in its political and religious aspects." The importance of 
these two volumes lies in the rich material which is brought together from remote archives and correspondence and eloquently presented. The reader becomes more and more aware of the great significance of the "satellites" on all sides of the three main disputants, and especially the leading role of the Strasbourg Reformer, Martin Bucer, in the progress of the Reformation. One also sees the significance of the efforts for political unity made by Philipp of Hesse and the evangelical imperial cities, and the paralysis of these cities at the hand of Luther's refusal to oppose the "government" of the emperor and a political protection of the gospel in general. The first volume's main contributions to research are its presentation of the rich mediaeval materials on which both parties drew. ${ }^{53}$ A further contribution is its

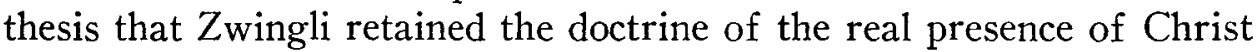
in the Lord's Supper until 1524, far into his Reformation period, and that only under the influence of the famous letter of the Dutchman Hoen did he arrive not only at a tropological exegesis of the words of institution, but also at a completely symbolical understanding of the Lord's Supper. Finally, Köhler notes the fact that "the controversy about the Lord's Supper gave birth to the concept of the essentials in religion, ${ }^{54}$ which, however, was supported only by the Zwinglians and not the Lutherans." "Luther and I have the same belief about and in Christ Jesus our Lord," writes Zwingli to a Roman opponent. The second volume portrays $Z$ wingli's growing involvement and eventual entanglement in various attempts at political concord. It impresses upon one Luther's stubborn insistence on the literal word of Scripture and Bucer's burning, untiring zeal for the unity of the Church, even where its diplomatic adaptability borders on untruth. The debate both before and after Marburg was carried on by both sides with philosophical arguments. Luther used scholastic arguments when he supported the doctrine of the ubiquity of the Body of Christ with the idea that God is "above mathematics" and that the dextera $d e i$ is non-spatial. Zwingli also used scholastic arguments when he was on the defense, but humanistic-Platonic arguments when he was presenting his own case: the sense process can have no effect on the soul.

In his treatment of the Marburg Colloquy, Köhler ${ }^{\mathrm{B5}}$ remarks in passing, concerning the disagreement over the relation of spirit and nature and the competence of reason in religious matters, "In Zwingli and Luther Humanism and thoroughgoing Biblicism were opposed, as well as Thomas Aquinas and William Occam, their common teachers in their student days, and Plato and Aristotle." The problem must be formulated more sharply. From the point of view of the history of dogma the via antiqua ( $Z$ wingli) and the via moderna (Luther) meet one another in the exegesis of a text ("This is my body"). Here lies an important task for research. ${ }^{\text {se, }}{ }^{\mathrm{st}}$ 
The heart of the $Z$ winglian protest, it seems to me, has not yet been exposed. ${ }^{58}$ This discloses itself first of all to the person who frees himself from the predisposition to find rationalism in $\mathrm{Zwingli}$. "Absurditatem non metimur ab ipsa re . . Quod si quid fidei absurdum, id tandem vere absurdum est." ${ }^{\text {"59 }}$ Zwingli's opposition to Luther's sacramental realism arose not from his rationalism but his Christology, for the sake of the complete and sole validity of the reconciliation accomplished on the Cross. If reconciliation occurred there, then comfort for the tempted soul must depend on the celebration of the Sacrament-an alternative which Luther could not recognize on the basis of his presuppositions. However memoria, "meal of memory," is likewise no intellectual procedure and does not simply arouse association with the historical past, but posits (following Augustine) the soul's power of representations in the consciousness. ${ }^{57}$

7. Zwingli's doctrine of the Lord's Supper intends to guard the Reformation sola fide against sacramental ceremonialism, which would be a form of creature-deification. Therefore, he conceives the Divine Service to be a Preaching Service. However, he does not consider it to be a Service for rational instruction, as many would expect, but rather a Service of traditional practices, liturgically rich and moving, adopted by free application. "Luther purified-Zwingli created," this was the surprise which Fritz Schmidt-Clausing, himself a Lutheran, a student of Leonhard Fendts and a follower of the movement of liturgical renewal, discovered in his book, Zwingli als Liturgiker. ${ }^{60}$ A distinctive feature of the Zürich liturgy, demonstrating Zwingli's patient and wise leadership of the young Reformed communities-he was not the impatient fanatic that many have claimed he was!--is the unexpected fact that it retained up to 1563 in its Divine Service of Preaching the traditional "Angelic Annunciation," the German Ave Maria, which was because of its popularity, simply indispensible. To be sure it had a characteristically evangelical introduction: "Let us also consider the incarnation of Christ which the angel Gabriel announced to the Virgin Mary and which was soon afterwards praised and lauded by the Holy Spirit through Elizabeth in these words: 'Hail Mary, O favored One . . .etc.' ",61, 82

The Deluge Prayer in the Baptismal Service has its example in Luther's Taufbüchlein of $1523{ }^{63}$ In Wittenberg "the boundless mercy of God" was implored, so that the child to be baptized "might be kept dry and safe in the holy ark of Christianity"; in Zürich, so that he might become "incorporated in Thy Son."

Those interested in liturgy were delighted with the interpretation of the Zürich liturgy of the Lord's Supper of 1525 by the Basel Practical Theologian, Julius Schweizer. ${ }^{64}$ He offers an intensive historical, liturgical and psychological interpretation of the same. For 
the systematic theologian and historian of Christian thought this opened up an important new source, the actual celebration. For Zwingli's theoretical writings on the Lord's Supper were all polemical. $\mathrm{He}$ who has assimilated this description of the intense emotion and the lively and joyful participation of the community, can no longer maintain that the Lord's Supper was regarded by Zwingli as unimportant. Again a typical feature: exactly at the place were transubstantiation takes place in the Mass, the congregation in Zwingli's formula is addressed as changed into the Body of Christ. ${ }^{65}$ Zwingli concludes the Divine Service of Preaching with the Public Confession of Sins-without absolution; in my opinion this is an unprecedented consequence of his prophetism. Schweizer's conjecture that Zwingli intended the celebration of the Lord's Supper to follow this service every Sunday (as Absolution), is likely to be a subject of discussion.

In his theology of worship I think that Zwingli's spiritualism must be underlined. The whole Reformation learned that the real presence of the Lord of the Church was to be found fundamentally in the viva vox evangelii instead of in the Sacrament. But Zwingli adds: the verbum qua externum has no power unless the Holy Spirit also speaks it inwardly. ${ }^{66}$

A discovery made by Oskar Farner shortly before his death belongs here and must be mentioned. Some had the idea that the (highly musical) Reformer wished to oppose the Latin hymn in his radical abolition of Kirchengesang. In an old as yet unpublished copy of Zwingli's lecturers on the Psalms, Farner found the statement: "If the hymn on Sunday is sung clearly and understandably for all, it is good and praiseworthy." 67 The old proposition, "Zwingli was opposed to Church Hymns," is no longer true.

8. It is generally observed that Zwingli had a different conception of the state than Luther who was loyal to the magistrates, and that Zwingli was prepared not only in the state of emergency but also on principle to confer on the Christian magistrate even responsibility for the Church. It is also generally known that Zwingli held that the Church is charged with the prophetic-critical "office of Watchman" vis-à-vis the government (according to Ezek. 3 and 33), and that the people possess the right of opposition to a magistrate who has strayed "outside the guidance of Christ." For the first time, our generation is beginning to see that these theses are not only the expression of Swiss Republican tradition but are also fundamentally a theological position. Still valid as the standard work on Zwingli's doctrine of the state is that of the jurist, Alfred Farner, who died young. ${ }^{68}$ It presents a richness of materials in a masterful piece of workmanship. His main thesis is that Zwingli, as well as the whole Reformation, exploded the mediaeval social order, which has been called in a ques- 
tionable manner the corpus christianum. Thus he interprets Zwingli in the same way that Karl Holl interpreted Luther in his famous controversy with Ernst Troeltsch and Walther Köhler. In his brilliant work Alfred Farner overshadowed the simple but solid dissertation of Paul Meyer, ${ }^{69}$ who had demonstrated merely by the combination of sources, how much Zwingli-and Luther also-thought in the context of the corpus christianum. Whoever takes the social and ethical statements of the Reformers not merely in isolation, but looks at them in the light of the Reformers' respective conceptions of the heart of their faith, ${ }^{70}$ must be convinced that the "modern" Troeltsch and his friends better understood the "mediaeval" character of the Reformation. It set up and continued in a new form the ideal of a unified Christian culture with its State Church territories. The jurist Calvin, $^{71}$ a refugee and organizer of the refugee congregations, was the first to separate church and state and to distinguish their competencies.

Zwingli's pronounced thoughts on politics are to be observed against the background of the disassociation of imperium and sacerdotium and the resistance to the fermenting and also religious anarchy. ${ }^{\mathbf{7 2}}$ This regard for the concrete situation is worked out in two special studies still to be mentioned. They are not of equal value. It is carried out most prominently in the learned and careful dissertation by the Catholic historian, Siegfried Rother, on Zwingli's Grundlagen. ${ }^{73}$ He sees in Zwingli a forerunner of Cromwell conscious that he was called to erect the Kingdom of God with armed force. $\mathrm{He}$ is correct in that faith and political action for Zwingli are not opposites, but both are grounded in the will and providence of God, and that it is not correct therefore, to speak of a change in Zwingli's thought around 1525 due to his sole reliance on the proclamation. In spite of numerous theological deficiencies and incorrect judgments the book offers a number of fruitful insights, the most informative of which may be the (first) attempt to explain what Zwingli intended in Marburg by his striking and philosophically formulated sermon, De providentia. Rother explains it as a comprehensive altercation of evangelical faith with the spirit of the time and its trends, particularly with the Renaissance belief in fate. This is worthy of attention.

In his monograph on Zwingli's doctrine of righteousness ${ }^{74}$ Heinrich Schmid is thorough. As a theologian Schmid owes allegiance to no school, and as a philologan he is well prepared. His command of the sources, including the often neglected Exegetica, is astonishing. In contrast to Rother he maintains that $Z$ wingli did not value the civil law very highly. Yet $Z$ wingli regarded its broken righteousness to be an expression of the preserving and healing will of God: it provides the milieu in which the Christian can strive after the higher righteousness of the Sermon on the Mount. Thus $Z$ wingli goes further 
in establishing a social ethic than Luther. Over against all this, the gratuitous righteousness of God is sui generis.

Especially informative are the well-reasoned formulations of Helmut Kressner in his chapter on Zwingli. ${ }^{75}$ To be sure his book, which was written in 1941, holds that Zwingli's moralism was grounded in pure Humanism, but it brings clearly to light that $Z$ wingli's politics arose from his faith, which for him was a will pressing for practical realization.

Kressner points out that in South Germany the associational character of the state and in Switzerland the community Church approached the evangelical congregation principle, and made it possible for Zwingli "to bridge the gap between the spiritual and worldly spheres." ${ }^{\prime 3}$ The fascinating work of Bernd Moeller, ${ }^{77}$ which just appeared, traces the relationship of the citizenry to the ZwinglianBucerian Reformation. He reports on the powerful advances of Zwinglianism in the South German imperial cities even after Kappel of 1531 . It was political difficulties, particularly the catastrophy of the Schmalkaldic War, foreseen by Zwingli as imminent, which brought on the transition to Lutheranism. With this transition the collapse of the freedom of the imperial cities and the disintegration of associational life went hand in hand. Absolutism entered upon its triumphant advance and the German Protestant became a pious "subject."

9. The multiple peculiarities of the $Z$ winglian voice in the choir of the Reformation movement, which have been enumerated here, was the occasion to ask once again about the central motif of his breakthrough, ${ }^{78}$ in the hope to find in this way also the unifying principle of his thought. Wernle and Köhler deny the existence of such a principle. Humanism as the form of his development and thought shaped Zwingli permanently -as it did more or less all the Reformers, even Luther but especially Calvin. But that does not suffice as an answer here, as the example of the venerated teacher, Erasmus, proves. The patriotism of the confederate who cares about the harm done his people goes further in helping us here. Without a doubt the practice of the late mediaeval, South German Preaching Service, the pronous, and the instruction by its most prominent theological and liturgical representative in Basel, Johann Ulrich Surgant, helped to form the Zwinglian Reformation, as Fritz Schmidt-Clausing recently has proved in an instructive dissertation. ${ }^{79}$ But the transition-about $1514 / 15$-to sola scriptura is crucial. ${ }^{80}$ To be sure Scripture was read for a while with the eyes of a Humanist, but in his reading of Scripture the experience followed that the living Christ himself is present in and demands obedience to, the rediscovered Word of the Bible, its interpretation and preaching. $Z$ wingli repeatedly has dated the beginning of this experience in the year 1516. The parable of the Talents, and the fear 
to be found standing as a "lazy servant when the Lord comes," played a special role in his perception of the urgency of the demands for Reformation. ${ }^{81}$ Here lies the root of his drive for practical realization mentioned above. Under the influence of reading the prophets a special experience also supervened: the fear of judgment for the temporal and eternal salvation of his people and the whole of Christendom. Christ who is present anew in the resounding gospel is the last chance, the final proclamation of the right to return home ("postliminium'). This is Zwingli's own testimony.

From this point all things could be explained: the cultural concern in the Zwinglian Reformation, in which Humanism changed from a motif to an instrument; spiritualism, which began with the ethical alternative between God's Word and selfishness; and the emphasis on the divinity of Christ and the corresponding theocratic efforts. The result of this would be that a complete interpretation of Zwingli's theology must be undertaken precisely in the light of his Christology. The first volume of my book is the introduction to such an interpretation. $^{\mathbf{8 2}}$

10. A detailed and new Überblick über Zwinglis Gedankenwelt which is highly noteworthy and deeply understanding has appeared from the pen of the Dominican, J. V. M. Pollet, in the Dictionnaire de Théologie catholique. ${ }^{83}$ In an exemplary manner it embraces the biblical, ancient and mediaeval elements in Zwingli's world of thought, and the discussion of the age. The main line of Zwingli's thought is a Christian spiritualism, ${ }^{84}$ which, by virtue of Platonic-Stoic-Erasmian influences, developed into rationalism in his doctrine of the Sacraments. Zwingli's prophetism is conceived as the key to his personality and taken earnestly throughout. His Christology, however, although painted in its "Nestorian" color, is not seen in its central position, neither are his political-social motives. But on the whole as in detail it is a reliable and clear report, undergirded with quotations! Crucial is the fact that the influence of Duns Scotus is evaluated more strongly than is usually done. It is acknowledged that Zwingli's Reformation regarded itself as opposed to creature-deification: but the absolute break between Creator and creature is not biblical but heathen in origin, and Zwinglianism was an attempt "d'incorporer à la dogmatique chrétienne des éléments, qui ne sont pas chrétiens, mais paiens ..."

Thus the task remains to separate the biblical basis of his thought and the humanistic forms of expression from one another. The first part of Theologie Zwinglis has shown that the greatest number and most important concepts of Zwingli's doctrine of God, which are usually regarded as "humanistic," are actually scholastic and consequently should be interpreted according to Thomas Aquinas; that Zwingli's 
so-called "Pantheism" is in reality something quite different, namely, an extreme theistic Monarchianism $;^{86}$ and that his theological as well as Christological statements flow into a covenant theology of Deus noster. ${ }^{87 .} 88$

\section{The Influence of Zwingli}

1. Up to a short time ago the origins of the Anabaptist Movement lay in darkness. My teacher, Fritz Blanke, has proven now in subtle investigations that the first Anabaptist community was a revival movement called forth by the preaching of Zwingli, which set out on its oppressed way from Zollikon near Zürich through the whole of Europe in search for a Church freed from the state. ${ }^{8 \theta}$ This discovery has given to Anabaptist research a powerful impetus. It would require its own report. ${ }^{30}$

2. We are slowly beginning to realize that also the direct influence of $Z$ wingli was stronger than one had long assummed. In addition to the aforementioned writing of Bernd Moeller, ${ }^{77}$ one is referred to Eekhof's ${ }^{91}$ article of 1919, which has become famous. He discusses Zwingli's influence in the Netherlands. However, Zwingli's influence there was soon to be superseded by his greatest disciple, Heinrich Bullinger, who was a true ecumenical figure. ${ }^{22}$ The bridge to Anglican England was made through Martin Bucer, through Doctor Thomas Erastus from Aargau and through the refugees under Bloody Mary who fled to Zürich. ${ }^{93}$ More important still than the individual special doctrines of Z $Z$ wingli-which were to be over-shadowed immediately within the Reformed Church by the self-contained system of Calvinism-were his stimuli. Johannes a Lasco from Poland, the creator of our Formulare, during his lifetime traced with thankfulness his final conversion to Evangelical faith back to a short encounter with Zwingli. Zwingli's "Prophezey" was imitated in the Netherlands, in the Palatinate and in England. It became the cradle for a Biblicism wrought by the aid of Philology and survived alongside the "Loci Method" of Orthodoxy.

Finally, Zwingli's Christian responsibility for public life with its specific social impact inspires up to today the religious-social movement in all countries. For the special charisma of the Zürich Reformer was his joyful confidence in the world-transforming power of the Word of God" : "Truly, the Word of God has its course as certain as the Rhine; one may dam it up for a long time but never obstruct it.",95

1. The journal, Vox Theologica: interacademical theologisch tijdschrift, is published by the foundation, "Verenigde $\mathrm{S}$ t udenten in de Theologische Faculteiten in Nederland,' and its publisher van Goreum and $\mathrm{Co}$. in Assen. All confessions are represented on the editorial staff, including the
Roman and Old Catholic confessions. The article appeared in Vol. 32.6 (Aug. 1962), and due to many requests is published here in a somewhat expanded form for German speaking territories. I am making full use of the willingness of the editors of Zwingliana because it affords me the 
opportunity not only to give a retrospective view but also to attempt by reason of the report to clarify and verify the questions and tasks of Zwingli research today. With the request of everyone's pardon let it be noted in the beginning that several of the main lines of research shall be set forth here and that the selection which of necessity at times has been arbitrary must leave unmentioned even important aspects of work done in the last decade.

2. Ulrich Zwingli: Eine Auswahl aus seinen Schriften, auf das Vierhundert jährige Jubiläum der Zürcher Reformation im A uftrag des Kirchenrats des Kantons Zürich, übersetzt und herausgegeben von Georg Finsler, Walther Köhler and Arnold Rüegg. Zürich, 1918. Paul Wernle: Der evangelische Glaube nach den Hauptschriften der Reformatoren. Band II: Zwingli. Tübingen, 1919. Walther Köhler: Huldrych Zwingli. Leipzig, 1943. Zweite, durchgesehene Auflage, Leipzig, 1954.

The progress of $\mathrm{Z}$ wingli research is reflected in the first place in the reg. ular articles and reports of the semiyearly journal, Zwingliana: Beiträge zur Geschichte Zwinglis, der Reformmation und des Protestantismus in der Schweiz (abbreviated Zwa). Zürich, since 1897. Published by ZwingliVerein in Zürich; edited by Leonhard von Muralt since 1934.

Obituary notice of Walther Köhler (by Leonhard von Muralt) and picture in $\mathrm{Z}$ (ef. note 8), VI, I (1961).

3. J had heard the story with my own ears from my teacher in Zwingli studies, Oskar Farner.

4. Walther Köhler already arrived at this view which was fundamental for the rest of his Zwingli research, in his analysis of "Zwingli as Theologian," Ulrich Zwingli: zum Gedächtnis der Zürcher Reformation. Zürich, 1919. Ulrich Zwingli und die Reformation in der $S$ ch weiz Religionsgeschichtliche Volksbücher IV, 31/32. Tübingen, 1919. Die Geisteswelt Ulrich Zwinglis, Christentum und Antike. Gotha, 1920.

5. Cf. also Walther Köhler's article, "'Zwingli," in RGG, zweite Auflage.

6. Huldreich Zwinglis Werke. Erste vollständige Ausgabe durch Melchior Schuler und Johannes Schulthess. 8 Bände in 10. Zürich, 1828-1842. Supplementorum fasciculus von Georg Srhulthess und Kaspar Marthaler. Zürich, 1861. (The hitherto eustomary abbreviation, SchSch or SS has been replaced by the letter $S$ followed by the Roman numeral of the volume number. See Zwa $X, 582$ ).

7. This applies especially to the much discussed Marburg Sermon, De providen. 'in a'd the confessional books, Fidei Ratio and Fidei Expositio in the small volume S IV.

8. Huldreich Zwinglis Sämtliche Werke. Unter Mitwirkung des Zwinglivereins in Zürich herausgegeben von Emil Egli†, Georg Finslerf, Walther Köhlert, Oskar Farnert, Fritz Blanke, Leonard von Muralt, Edwin Künzli, Rudolf Pfister. Corpus Reformatorum Volumina LXXXVIIIff. Berlin, later Leipzig, recently Zürich, 1905ff. (In the notation of the literature a great deal of confusion has reigned. CR with the Roman numeral was subject to misunderstanding and difficult to read; $\mathrm{ZW}, \mathbf{S W}, \mathrm{W}, \mathbf{K A}, \mathbf{K}$ (= sämtliche Werke, Kritische Ausgabe) have all been replaced since 1958 by $\mathrm{Z}$ followed by the Roman numeral of the volume number; v. loc. cit. Zwa $\mathrm{X}, 582$ ).

9. Here as elsewhere we have seen the importance of the fact that the Swiss had neither a 30 or an 80 years war. Compared with the Netherlands and Germany our arehives are rich in documents from the period before the 17 th century.

10. Olrich Zwingli: Eine Auswahl aus seinen Schriften auf das vierhundert. jährige Jubiläum der Zürcher Reformation im Auftrag des Kirchenrats des Kantons Zürich, übersetzt und herausgegeben von Georg Finsler, Walther Köhler und Arnold Rüegg. Zürich, 1918.

11. Huldrych Zwingli: Auswahl seiner Schriften, herausgegeben von Edwin Künzli.

12. Zwingli-Hauptschriften. Bearbeitet von Fritz Blanke, Oskar Farner, Oskar Frei, Rudolf Pfister. Zürich, 1940ff. To date 7 volumes: 1-2 Der Prediger; 3-4 Der Verteidiger des Glaubens; 7 Der Staatsmann; 9 und 11 Der Theologe.

13. Huldrych Zwingli: Christliche Anleitung. Ins Neudeutsche übertragen und herausgegeben von Gerhard G. Muras. Furche-Verlag, Hamburg, 1962 (Furche-Bücherei Nr. 207). The translation is modern and clear, yet without com. pletely loosing the flavor and fineness of the original. In the foreword we read that the purpose of the publication is the following: "Einmal möchte sie dazu beitragen, dem deutsehen volk neben Martin Luther auch Huldryeh Zwingli nahezubringen. . . . Andererseits will diese Wiederherausgabe mit Entschiedenheit die Geistesverwandtschaft der beiden Reformatoren deutlich machen und die Lebensgemeinschaft ihrer Kirchen fördern. So möchte diese Veröffentlichung im Nebenzweck die Freundschaftsgabe eines Unionslutheraners an die Reformierte Schweiz sein ....",

14. Huldrych Zwinglis Briefe. Ubersetzt von Oskar Farner. Band I: 1512-1523. Zürich, 1918. Band II: 1524-1526. Zürich, 1920.

15. Huldrych Zwingli: Von göttlicher und menschlicher Gerechtigkeit. Sozi al- 
politische Schriften für die Gegenwart ausgewählt und eingeleitet von Leonhard von Muralt und Oskar Farner. Zürich, 1934 .

16. Inter alia: André Bouvier: "Ulrich Zwingli d'après ses oeuvres," Revue de theologie et de philosophie, 1931, pp. 205-232. P. Mesnard: "La pédagogie évangélique de Zwingli."' (Traduetion de 'Quo pacto ingenui adolescentes formandi sint'). Revue Thomiste, 1953, pp. 367-386. Huldrych Zwingli, Brève instruction chrétienne (1523), traduite par Jaques Courvoisier. 1953.

17. Selected Work of Huldreich Zwingli, edited by S. Macauley Jackson. 1901. The Latin Works and the Correspondence of Huldreich Zwingli: Together with Selections from his German Works. Edited by Samuel Macauley Jackson . . 1912ff. (To date 3 volumes).

18. Huldreich Zwinglis Zeven en zestig artikelen en Korte christelyke inleiding. Vertaald en toegelicht door Gerardus Oorthuys. G. Oorthuys: "Uitleggen en gronden der stellingen ...." Troffel en Zwaard, 1909-1911. Overdruk in: G. Oorthuys: Kruispunten op den $W e g$ der kerk. Wageningen, 1935.

19. Oskar Farner: Huldrych Zwingli. Band I: Seine Jugend, Schulzeit und Studenten.Jahre 1484-1506. Zürich, 1943. Band II: Seine Entwicklung zum Reformator. 1506-1520 Zürich, 1946. Band III: Seine Derkündigung und ihre ersten Früchte 1520-1525. Zürich, 1954. Band IV: Reformatorische Erneuerung von Kirche und ..Volk in Zürich und in der Eidgenossenschaft 1525-1531; aus dem Nachlass herausgegeben von Rudolf Pfister. Obituary notice of Oskar Farner (1884-1958) by Fritz Blanke and picture in $\mathrm{Z}$ XIV. Oskar Farner: Erinnerungen. ZwingliBücherei 68. Zürich, 1954.

20. Walther Köhler: Huldrych Zwingli. Leipzig, 1943, 19542.

21. Of the numerous and popular presentations of Zwingli from the pen of Oskar Farner the following in my opinion is the most impressive: Oskar Farner: Die grosse Wende in Zürich. (It includes a photo of the ZwingliTüre in the Grossmünster in Zürich by Otto Münchs). Zürich, 1941. Oskar Farner: Der Reformator Dlrich Zwingli. Zwingli-Bücherei 60. Zürich, 1949.

22. The remarks published in the Zürich press on the occasion of the exhibition are given in the following: Paul Sieber: Bibliographie zum Z Z̈̈rher Taschenbuch auf das Jahr 1950, p. $187 / 8$. Cf. Hans Hoffmann: "Ein mutmassliches Bildnis Huldrych $Z$ winglis," Zwingliana VIII, 1948, pp. 497501.

23. In the National Gallery of Arts in Washington. (Kind information from Prof. Dr. Jaques Courvoisier in Geneva).
24. A good colored reproduction on a large post card can be obtained from the Kunstverlag Wolfrum, Wien I, Augustinerstrasse 10 .

25. Oskar Farner: Zwinglis Entwicklung zum Reformator nach seinem Briefwechsel bis Ende 1522. Zwa III, 19131915.

26. Arthur Rich: Die Anfänge der Theologie Huldrych Zwinglis. Zürich, 1949.

27. A recently published and exceedingly careful comparison of the young Reformer with his great teacher does not stop with the formal " training," but correctly deals with a central theme in detail: Joachim Rogge: Zwingli und Erasmus: Die Friedensgedanken des jungen Zwingli. Calwer Verlag, Stuttgart, 1962 (Arbeiten zur Theologie, hg. . . von Theodor Schlatter, Heft 11). Much can be learned about the beginnings of the preacher, the personal and social motives of the Reformer which were still in a partly unconscious status nascendi, from the line by line interpretation of parallel texts. In the changes of his outlook towards the question of peace he strove towards his typical principle of the unity of Christian and citizen.

28. Rich, loc. cit. p. 93 .

29. Gottfried W. Locher: "Elia bei Zwingli." Miszelle in: Judaica. Zürich, $\mathrm{XI} / \mathrm{I}, 1953$, p. $62 / 3$.

30. Joachim Rogge: Zwingli und Erasmus. Die Friedensgedanken des jungen Zwingli (v. note 26).

31. De gestis inter Gallos et Helvetios relatio (Fall, 1512). Z I, pp. 23-37.

32. Cf. Gottfried W. Locher: Das Geschichtsbild Huldrych Zwinglis," Theol. Zeitschrift. Basel, IX. Jg., 1953, Heft 4, pp. 275-302. G. W. Locher: Im Geist und in der Wahrheit. Die reformatorische Wendung im Gottes. dienst zu Zürich. (Nach Gottes Wort reformiert Heft 11). Neukirchen, 1957.

33. Gerardus Oorthuys: De anthropologie van Zwingli. Leiden, 1905.

34. Rudolf Pfister: Das Problem der Erbsünde bei Zwingli. Leipzig, 1939.

35. Gottfried W. Locher: Die Theologie Huldrych Zwinglis . . . ( pp. 137-139.

36. Cf. Paul Jacobs: Prädestination und Verantwortlichkeit bei Calvin. Nenkirchen, 1937. p. $67 \mathrm{ff}$.

37. S IV, 65. Cf. S VI, I, 583. S VI, II, 252. S IV, 123.

38. Paul Wernle: Der evangelische Glaube nach den Hauptschriften der Reformatoren. Band II: Zwingli. Tübingen, 1919. p. 353: "Es ist der von Erasmus und der Renaissance übernommene moralische Universalismus, den Zwinggli zeitlebens neben dem Paulinismus in seiner Seele getragen hat."

39. Walther Köhler: Huldrych Zwingli. Leipzig 19542. p. 235: "Es war ein Einbruch in die Ausschliesslichkeit christlichen Heilsbewusstseins, humanis- 
tisch, den Menschen wertend, ein Stück Wiederbelebung des klassisehen Altertums, denn auf Ciceros 'Traum Scipios' geht diese Sehilderung des verklärten Jenseits grosser Männer zurück ...'

40. Rudolf Pfister: Die Seligkeit erwählter Heiden bei Zwingli. Zollikon, 1952. "Zur Begründung der Seligkeit von Heiden bei Zwingli," Evangelisches Missions-Magazin 95, Basel, 1951, Heft 3, pp. $70-80$.

41. John 14:6. Cf. e.g. Z V, 629; S IV, 62. 42. S III, 572. R. Pfister: Zur Begründung .." loc. cit. EMM 1951, p. 74ff.

43. Here and for the following: Gottfried W. Locher: "Die Prädestinationslehre Huldryeh Zwinglis. Zum 70 . Guburtstag Karl Barths,', Theol. Zeit. schrift. Basel, 1956. Heft 5, pp. 527. 548 (p. 542f).

44. S IV, p. 7.

45. Cf. Conf. Belg. Art. XVI.

46. S IV, p. $5 f$.

47. In order to establish more clearly Zwingli's doctrine of election, its place in the general history of dogma and its own pecular interpretation of the question of supralapsarianism or infralapsarianism which was much closer to the Bible than the 17th century interpretation, we must refer to the article mentioned in note 43 .

48. Walther Köhler: Das Marburger Religionsgespräch 1529. Dersuch einer Rekonstruktion. Schriften des Vereins für Reformationsgeschichte, Jg. 48/1, Nr. 148. Leipzig, 1929.

49. P. 27.

50. P. 38

51. P. 30

52. Walther Köhler: Zwingli und Luther. Ihr Streit über das Abendmahl nach seinen politischen und religiösen $B e^{-}$ ziehungen. Band I: Die religiöse und politische Entwicklung bis zum Marburger Religionsgespräch 1529. Leipzig, 1924. Band II: Vom Beginn der Marburger Verhandlungen 1529 bis zum Abschluss der Wittenberger Konkordie von 1536. Heraugegeben ron Ernst Kohlmeyer und Heinrich Bornkamm. Gütersloh, 1953.

53. E.g. Band I, pp. 806-812.

54. P. $829 \mathrm{ff}$.

55. Band II, p. 137 .

56. Important new sources concerning the Eucharistic controversy have led to a careful study: Joachim Staedtke: "Eine neue Version des sogenannten Utinger-Berichtes vom Marburger Religionsgespräch 1529," $Z_{w a} X, 210$ 216; and Fritz Büsser in his edition of Beschreibung des Abendmahlsstreites von Johann Stumpf, Zürich, 1960.

57. In the continuation of my Theologie Zwinglis ( $\mathrm{v}$. note 82 ), I hope to discuss these problems in greater detail.

58. One is directed to the following: Gottlob Schrenk: "Zwinglis Hauptmotive in der Abendmahlslehre und das Neue Testament,' Zwa V/4, 1930/2, pp. 176-185. Fritz Blanke: "Zwinglis Sakramentsanschauung," Theol. Blätter, 1931, col. 283-290, Wilhelm Niesel: "Zwinglis 'spätere' Sakramentsanschauung,' Theol. Blätter, 1932/1. Fritz Blanke: "Antwort auf W. Niesel, Zwinglis 'spätere' Sakramentsanschauung," Theol. Blätter, 1932, col. 18. Fritz Blanke: "Zum Verständnis der Abendmahlslehre Zwinglis," Pastoraltheologie, 1931, pp. 314-320. Gottfried W. Locher: In Geist und in der Wahrheit. Die reformatorische Wendung im Gottesdienst zu Zürich. (Nach Gottes Wort reformiert Heft 11). Neukirchen, 1957. "'Zwingli. II. Theologie," RGG, dritte Auflage, Tübingen, 1962. Col. 19601969.

59. Z V,618.

60. Fritz Schmidt-Clausing: Zwingli als Liturgiker. Eine liturgie-geschichtliche Untersuchung. Göttingen, 1952. Review by G. W. Locher: Musil und Gottesdienst IX/2, Zürich, März-April, 1955.

61. P. 107.

62. In 1950 in connection with the defin. ition of the bodily assumption of the Mother of God there was a controversy in the "Neuen Zürcher Zeitung," in which the Roman Catholic side maintained that even $\mathbf{Z}$ wingli held the same doctrine. We eite here only the conclusion of the debate: Zwingli says "Her sole honor is her Son." Gottfried W. Locher: "Inhalt und Absicht von Zwinglis Marienlehre." Complete in: Kirchenblatt für die reformierte Schweiz, 1951/3. The learned Catholic Karl Federer took up the argument once again: "Zwingli und die Marienverehrung," Zeitschrift für schweiz. erische Kirchengeschichte, 1951, pp. 1326 ; however, he was repudiated by a specialist in the South German and Swiss Reformation, namely, by the Dominican, J. V. M. Pollet. "'Recherches sur Zwingli," Revue des Sciences Religieuses, Strasbourg, tome 28, avril 1954, pp. 167-169). The latest study, Marienlob der Reformatoren by Walter Tappolet (Zürich, 1961), does not contribute anything new, but allows the actual proclamations about Mary to be brought forward in a prominent manner.

63. Index, p. 152/153.

64. Julius Schweizer: Reformierte Abendmahlsgestaltung in der Schau Zwinglis. Basel, 1954.

65. P. $103 f$.

66. Gottfried W. Locher: Im Geist und in der Wahrheit. Die Reformatorische Wendung im Gottesdienst zu Zürich. (Nach Gottes Wort reformiert Heft 11). Neukirchen, 1957. pp. 16-19.

67. Oskar Farner: "Eine neuentdeckte Ausserung Zwinglis über den Gemeintdegesang," Jahrbuch für Liturgik und Hymnologie 1957, p. 130. 
68. Alfred Farner: Die Lehre von Kirche und Staat bei Zwingli. Tübingen, 1930.

69. Paul Meyer: Zwinglis Soziallehren. Linz a.D., 1921.

70. Gottfried W. Locher: Die evangelische Stellung der Reformatoren zum öffent. lichen Leben. Kirchliche Zeitfragen Heft 26. Zürich, 1950. "Das Problem der Landeskirche,"' Evangelische Theologie 1956/1, pp. 33-48.

71. Gottfried W. Locher: Calvin - Anwalt der Okumene. Theol. Studien, hg. von Karl Barth und Max Geiger, Heft 60 . Zollikon, 1960.

72. In place of all the older treatments mention should be made of the short but comprehensive interpretation which Leonard von Muralt has contributed to Historia Mundi concerning the political history of the Zürich Reformation. We cannot go into further detail here. "Die Reformation", Historia Mundi, Ein Handbuch der Weltgeschichte in zehn Bänden. VII: Ubergang zur Moderne. 1957, pp. 39-118; 'Zwingli,' pp. 69-74. His articles, "Italienischer Humanismus und Zwinglis Reformation," Zwa $X, 398-408$, and "Renaissance und Reformation in $\mathrm{der}$ Schweiz," Zwa XI, 1-23, give us a clear insight into the workshop of the master. A series of comprehensive treatments which will be published soon by his students (Martin Haas, Kurt Spillmann, René Hauswirth and others), promise us an even more unexpected explanation of Zwingli's complicated political connections.

73. Siegfried Rother: Die religiösen und geistigen Grundlagen der Politik Hul. drych Zwinglis. Ein Beitrag zum Problem des christlichen Staates. Frlangen, 1956.

74. Heinrich Schmid: Zwinglis Lehre von der göttlichen und menschlichen Ger. echtigkeit. Zürich, 1959.

75, Helmut Kressner: Schweizer $\bar{U}$ sprünge des anglikanische Staatskirch. entums. Gütersloh, 1953. Erik Wolf: "Die Sozialtheologie Zwinglis," Fest. schrift Guido Kisch. Stuttgart, 1955.

76. P. 33 .

77. Bernd Moeller: Reichsstadt und Reformation. Gütersloh, 1962.

In addition, the still indispensable study: Leonhard von Muralt: Stadt. gemeinde und Reformation in der Schweiz. Zürich, 1930.

78. Gottfried W. Locher: "Das Geschichtsbild Huldrych Zwinglis," Theol. Zeitschrift, Basel, 1953, p. $275 \mathrm{ff}$. Der Eigentumsbegriff als Prob: lem evangelischer Theologie. Zürich, 19622. Erster Teil, drittes Kapitel: "Zwingli. Die politische Verantwortung der Christenheit und das Eigentumsproblem.' pp. 29-35, 49-53. Hul. dryeh Zwinglis Botschaft," Zwa $X$, $591-602(1958 / 2)$.
79. Fritz Schmidt-Clausing: "Johann Ulrich Surgant, ein Wegweiser des jungen Zwingli," Zwa XI/5, 287-320 $(1961 / 1)$

80. "Ich hub mich an gantz an die heyligen gschrifft lassen."' $\mathrm{Z}$ I, 379 .

81. Z I, 256; 316.

82. Gottfried W. Locher: Die Theologie Huldrych Zwinglis im Lichte seiner Christologie. Erster Teil: Die Gotteslehre Zürich, 1952. Cf. also: Locher: "' 'Christus unser Hauptmann.' Ein Stück der Verkündigung Huldrych Zwinglis in seinem kulturgeschichtlichen Zusammenhang," Zwa IX/3, 121$138(1950 / 1)$.

83. J. V. M. Pollet, O.P.: “Zwinglianisme," Dictionnaire de Théologie cath olique. Tome XV, col. 3745-3928. Paris, 1951.

84. Concerning Zwingli's spiritualism, $c f$.: Erich Seeberg: "D e r Gegensatz zwischen Zwingli, Schwenckfeld und Luther,' Reinhold-Seeberg-Festschrift. Leipzig, 1929. Helmuth Gollwitzer: "Zur Auslegung von Joh. 6 bei Luther und Zwingli," Evan. Theol., 1951, pp. 143-168.

85. G. W. Locher: Theologie Zwinglis. Band I (note 82), p. 95ff.

86. Pp. 99-133.

87. The detailed criticism of my book by J. V. M. Pollet, O.P., in his research report mentioned in note 62 is very instructive, pp. 159-160. The article "Zwingli" in the 3. Auflage of the RGG has appeared at the end, Vol. VI, 1962, col. 1952-1960 by Fritz Blanke: "I. Leben und Schriften"; col. 1960.1969 by G. W. Locher: "II. Theologie"'; additional reference should be made to the careful but very tentative attempt of the article to give a complete picture which has resulted from the present state of research.

88. P. 98. Christus noster: pp. 33-42.

89. Fritz Blanke: Brüder in Christo. Die Geschichte der ältesten Täufergemeinde (Zollikon, 1525). Zürich, 1955.

90. Cf. Quellen zur Geschichte der Täufer in der Schweiz. Band I: Zürich. Herausgegeben von Leonhard von Muralt und Walter Schmid. Zürich, 1952. Torsten Bergstén: Balthasar Hubmaier, seine Stellung zu Reformation und Täufertum 1521-1588, J. G. Oncken Verlag, Kassel, 1961, offers not only an instructive report on the politics of Zürich compared with that of Waldshut and its participation in the German Peasant's Revolt, but also in the first part gives an excellent survey of the present state of Anabaptist research and its theological as well as historical problems.

91. A. Eekhof: "Zwingli in Holland," Zwa III/12/13, 370-384 (1919/1).

92. Walter Hollweg: Heinrich Bullingers Hausbuch. Eine Untersuchung über die Anfänge der reformierten Predigt- 
literatur. Neukirchen, 1956. Joachim Staedtke: "Bullingers Bedeutung für die protestantische Welt," Zwa XI/6, 372-388 (1961/2).

93. H. Liermann: "Untersuchungen zum Sakralrecht des protestantischen Herrschers," Zeitschrift der SavignyStiftung, Kanon. Abt. 30, 1941. Ruth Wesel-Roth: Thomas Erastus. Ein Beitrag zur Geschichte der reformierten Kirche und zur Lehre von der Staatssouveränität. Lehr/Baden, 1954. Helmut Kressner:: Schweizer $\mathrm{Ur}^{-}$ sprünge des anglikanischen Staatskirchentums. Gütersloh, 1953. W. M. S. West: John Hooper and the Origins of Puritanism. Zürcher Dissertation, 1955. Rudolf Pfister: "Zürich und das anglikanische Staatskirchentum," Zwa $X, 249-256$.

94. The real and spontaneous consequences of the Zürich Reformer, though not easily understood, should be mentioned here. In these connections the tendenices can be seen which led to the Barmen Theological Declaration of 1934 (G. W. Locher: "Die Stimme des Hirten", Oskar Farner: Erinnerungen. Zürich, 1954, pp. 111-115), or his distinct impetus to the present-day discussion of baptism (inter alia: Fritz Schmidt-Clausing: " Zwingli und die Kindertaufe," Berliner Kirchenbriefe, Nr. 6, Okt. 1962), finally, his sudden and very real impetus to the diseussion of the subject, Council.

95. Z III, 4887-8. 